\section{A strong and unified voice for lung health}

$\mathrm{I}$ would like to update you on the National Lung Health Framework meeting, which took place in Ottawa, Ontario, on April 26 and 27, 2007. Over 190 participants met and worked very hard to develop a draft framework strategy and an initial plan of action. Following on the momentum of the interim Steering Group and the four Working Groups (Chronic Disease, Infectious Disease, Tobacco Control and Environment), tangible progress was made in essential framework components, including prevention, infrastructure, research and surveillance, and disease detection and management. While there were many representatives from various organizations, sectors and interested groups, I believe by far the greatest representation was from members of the Canadian Thoracic Society (CTS) and the Canadian Respiratory Health Professionals.

The CTS and the Canadian Respiratory Health Professionals have first-hand understanding of the issues affecting their patients. Because of our background and expertise, we are ideally suited to play a significant role in crafting a national lung health strategy, a strategy that will benefit our patients. As mentioned in the President's Page in the last month's issue of the Journal, the need for a coordinated and comprehensive approach to prevent and combat respiratory disease is clear, and the timing of the National Lung Health Framework meeting could not have been better. Speaking as both a group and an organization, but also as individuals with specific expertise in varying areas, our voices were loud and clear. It became readily apparent that priorities for members and organization in areas such as advocacy, funding, research intensiveness and patient care were shared by many - we were not alone, and our voices were heard. In fact, one of the learnings from the Framework was the importance and need of a strong and unified message, far beyond the CTS, speaking to the goals of the National Lung Health Framework and the pressing needs of our patients.

The Honourable Tony Clement, Minister of Health, opened the Framework meeting on Thursday, April 26, and in his address announced additional funding to support finalization of the Framework strategy. He also spoke specifically of this issue later that day in the House of Commons. The Honourable John Baird, Minister of Environment, closed the Framework meeting on Friday, April 27, 2007, with a review of both his recent environment bill and the 'Clean Air Act'. While there is much debate about some aspects of the recent legislature, there are many aspects of the legislation and the Clean Air bill that we can support. Given his busy schedule and activities that day, his presentation and attendance at the National Lung Health Framework speaks volumes to the audience listening to our voices on lung health and disease.

\section{Un point de vue solide et unifié en santé pulmonaire}

J

e tiens à vous informer de la réunion sur le Cadre de santé pulmonaire pour le Canada, qui a eu lieu à Ottawa, en Ontario, les 26 et 27 avril 2007. Plus de 190 participants se sont réunis et ont beaucoup travaillé pour évaluer un projet de cadre et un plan d'action initial. Poursuivant sur la lancée du groupe directeur provisoire et des quatre groupes de travail (maladies chroniques, maladies infectieuses, contrôle du tabagisme et environnement), ils ont réalisé des progrès tangibles dans des éléments essentiels du cadre, y compris la prévention, l'infrastructure, la recherche et la surveillance ainsi que le dépistage et la prise en charge des maladies. De nombreux représentants provenaient d'une variété d'organisations, de secteurs et de groupes intéressés, mais à mon avis, le plus grand nombre de représentants, et de loin, étaient issus de la Société canadienne de thoracologie (SCT) et des Professionnels canadiens en santé respiratoire.

La SCT et les Professionnels canadiens en santé respiratoire comprennent intimement les problèmes de leurs patients. En raison de leurs compétences et de leur expérience, ils sont en position idéale pour occuper une fonction importante dans la réalisation d'une stratégie nationale en santé pulmonaire, une stratégie qui sera bénéfique à leurs patients. Comme je l'ai indiqué dans la page du président du dernier numéro du journal, il est clair qu'il faut une démarche coordonnée et complète pour prévenir les maladies respiratoires et lutter contre elles, et le moment de la réunion sur le Cadre de santé pulmonaire pour le Canada n'aurait pu être mieux choisi. Nous exprimant à la fois en tant que groupe et d'organisme, mais également à titre de particuliers ayant des compétences précises dans divers domaines, nous nous sommes fait entendre haut et fort. Il est vite devenu apparent que nous étions nombreux à partager les priorités des membres et des organismes dans des domaines comme la défense d'intérêts, le financement, l'intensité de la recherche et les soins aux patients. Nous n'étions pas seuls, et notre point de vue a été entendu. En fait, l'un des apprentissages de cette rencontre, c'est l'importance et la nécessité d'un message solide et unifié, dépassant largement la SCT, axé sur les objectifs du Cadre de santé pulmonaire pour le Canada et les besoins pressants de nos patients.

Le jeudi 26 avril, l'honorable Tony Clement, ministre de la Santé, a ouvert la réunion, et dans son allocution, il a annoncé un financement supplémentaire pour soutenir la finalisation du Cadre. Il a également abordé directement ce sujet à la Chambre des communes, plus tard au cours de la journée. Le vendredi 27 avril, l'honorable John Baird, ministre de l'Environnement, a clos la réunion avec une analyse de sa récente loi sur l'environnement et de la Loi sur la qualité de l'air. Certains aspects de la récente loi sont très controversés, 
While much work has been performed and accomplished, and the efforts of many to date should be applauded, there is a great deal that remains to be completed. We are just in the midst of a process - our goals have not yet been attained. The representation and work of the Interim Steering Committee and various working groups will be expanded and the CTS will be asked to contribute to that work. It is clear that the CTS will be very well represented. As a national organization, we will be looking to many of you for your participation, your wisdom and your leadership in taking on various important roles on behalf of our organization.

I would like to sincerely thank you in advance for your time and commitment on behalf of the CTS for this important initiative. It is clear that we have the 'ear' of the federal government and it is clear that many others, besides the CTS and its members, are activated and engaged in participating in this process. With so many listening, now is the time for the CTS to speak with a strong and unified voice, particularly for the thousands too short of breath to be heard.

Darcy D Marciniuk MD FRCPC FCCP President, Canadian Thoracic Society mais nous pouvons en soutenir de nombreux éléments, de même que ceux de la Loi sur la qualité de l'air. Étant donné son horaire chargé et ses activités ce jour-là, son allocution et sa présence à la réunion du Cadre de santé pulmonaire pour le Canada en disent long sur l'auditoire qui écoute notre point de vue en matière de santé et de maladie pulmonaires.

Nous avons déjà accompli et abattu beaucoup de travail, et les efforts consentis par bien des gens jusqu'à maintenant méritent des félicitations, mais il reste beaucoup à faire. Nous sommes au cœur d'un processus; nous n'avons pas encore réalisé nos objectifs. Les représentants et le travail du comité directeur provisoire et des divers groupes de travail augmenteront, et la SCT sera invitée à y participer. De toute évidence, la SCT sera très bien représentée. En qualité d'organisme national, nous nous tournerons vers bon nombre d'entre vous pour profiter de votre participation, de votre sagesse et de vos qualités de chef à diverses fonctions importantes en notre nom.

Je vous remercie déjà du fond du cœur du temps et de l'engagement que vous consacrerez à ce projet d'importance pour le compte de la SCT. Il est clair que le gouvernement fédéral nous écoute et que bien d'autres intervenants, à part la SCT et ses membres, sont actifs et engagés dans ce processus. Puisqu'ils sont si nombreux à être à l'écoute, il est temps pour la SCT d'exprimer un point de vue solide et unifié, notamment au nom des milliers de personnes qui n'ont pas assez de souffle pour être entendues.

Darcy D. Marciniuk MD FRCPC FCCP Président, Société canadienne de thoracologie 


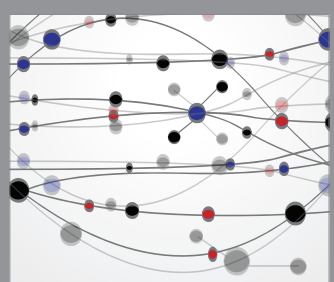

The Scientific World Journal
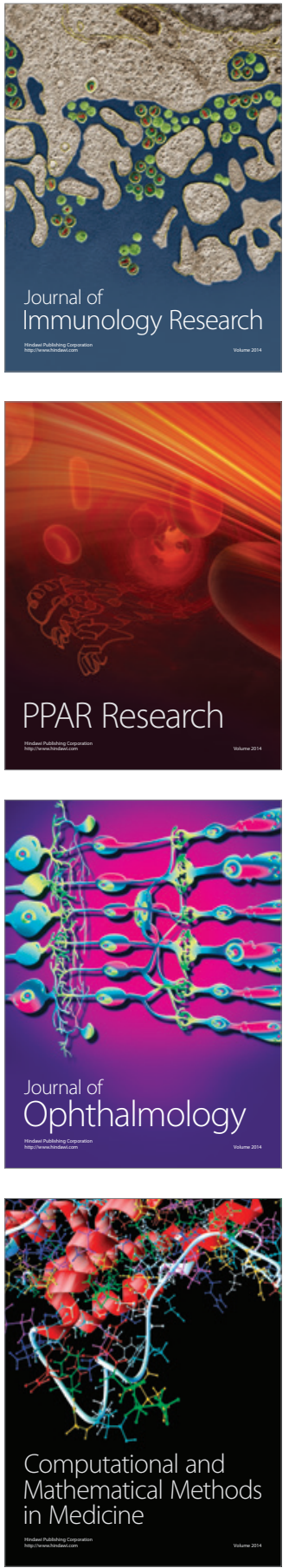

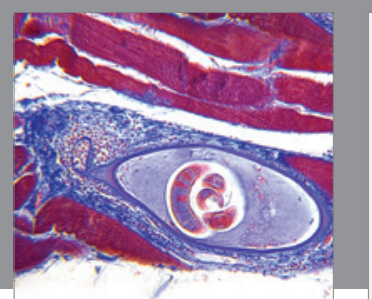

Gastroenterology Research and Practice

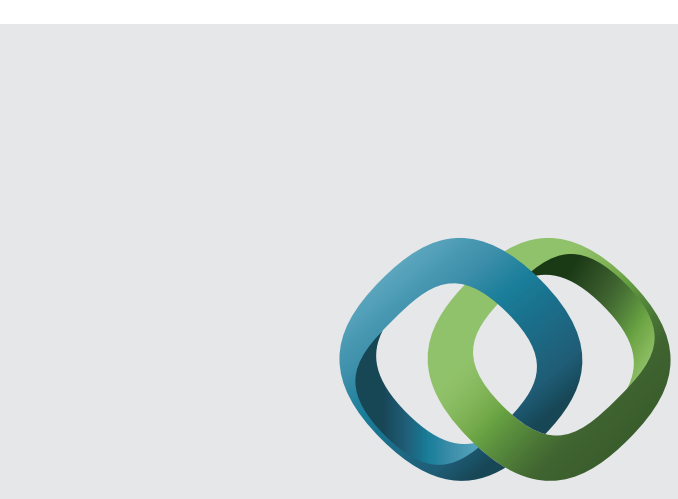

\section{Hindawi}

Submit your manuscripts at

http://www.hindawi.com
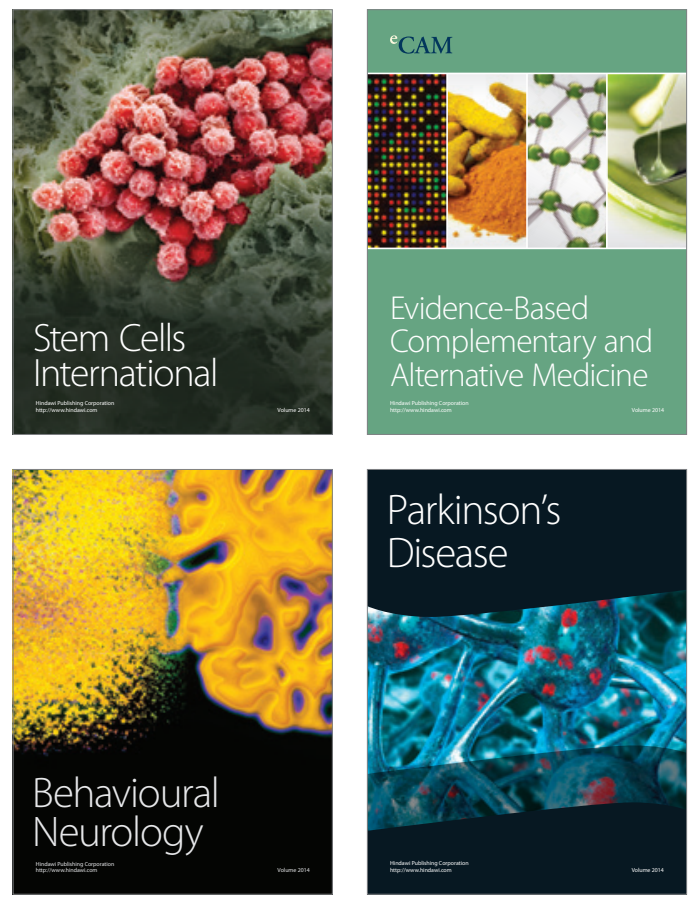
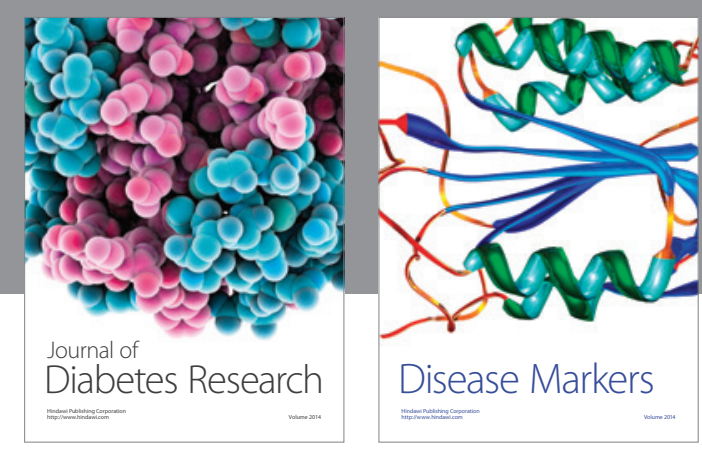

Disease Markers
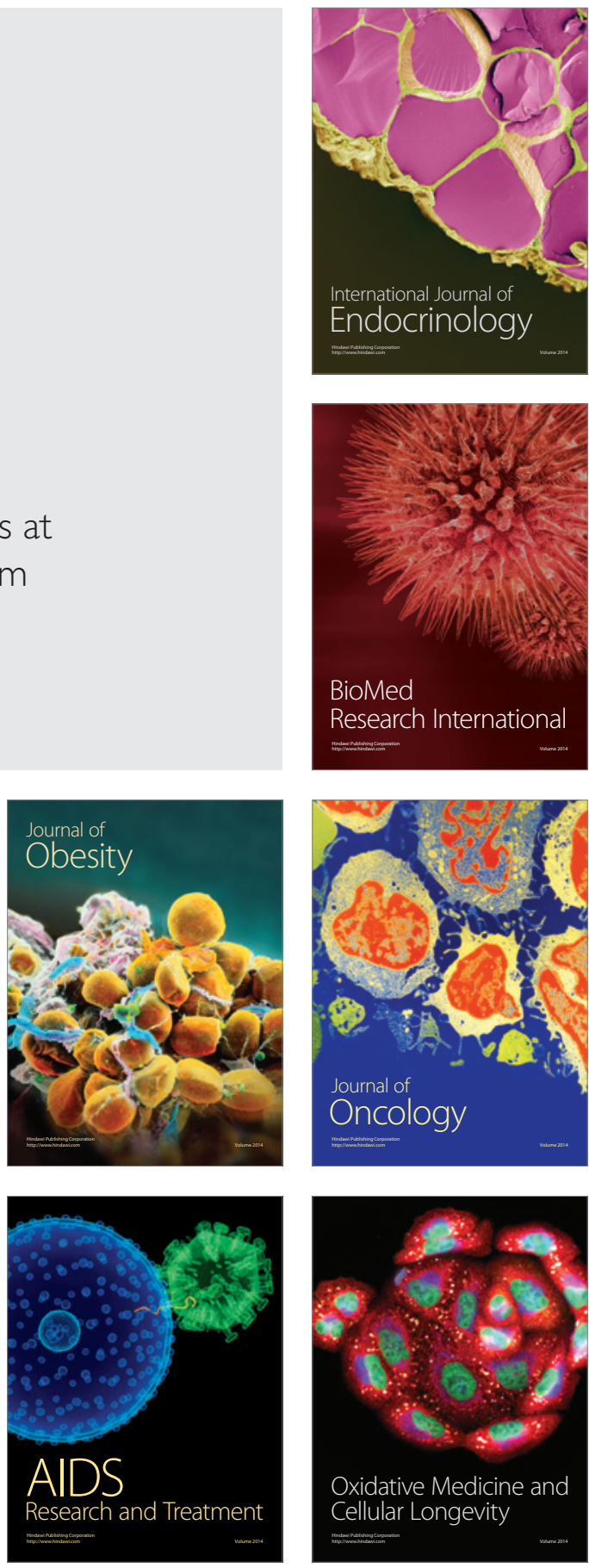